\title{
The Impact of Face-To-Face Tutorial and Administrative Support Services on Distance Education Students' Academic Performance at The University of Cape Coast
}

\author{
Aaron Kwadjo ${ }^{1}$, Samuel Yaw ${ }^{2}$ \\ ${ }^{1}$ Department of Education, University of Gothenburg, Sweden \\ kwadjoaaron@gmail.com \\ ${ }^{2} \mathrm{PhD}$, University of Cape Coast College of Distance Education Cape Coast , Ghana \\ yampofo1000@gmail.com
}

\begin{abstract}
A student survey was used to investigate the impact of face-to-face and administrative support services on the academic performance of distance education students at the University of Cape Coast. Data was collected from 374 respondents in nine study centres, three from each of the three study centre zones of the University of Cape Coast's College of Distance Education (Southern, Middle, Northern). The data was analysed using means, standard deviations, and correlation. According to the research, University of Cape Coast distance education students have a positive impression of the face-to-face tutorial services given. They did, however, express dissatisfaction with its administrative support. Analysis from the study showed a significant positive but weak relationship between face-to-face tutorial service and academic performance of distance education students. The study results further revealed a weak significant positive relationship between administrative, support services and academic performance of distance education students of the University of Cape Coast.
\end{abstract}

Keywords: face-to-face tutorials, administrative support services, academic performance

\section{Introduction}

Enrolment and demand for university education have increased at an unparalleled rate around the world, particularly in the twentieth and twenty-first centuries. This has been attributed mostly to the private and social benefits of higher education (Michubu, Nyerere, \&Kyalo, 2017).Governments in both developing and rich countries have attempted to make university education more accessible. Unfortunately, government support for expanding connectivity in Africa has been dwindling. Universities have been compelled to operate on tight resources, and in many cases, they have been overburdened in providing proper student support services, lowering the quality of university education (Nabi, Bhatti and Samina, 2013).

Countries try to improve higher education in part because successful use of "intellectual capital" benefits economies. The access support that institutions provide to students is an important component that influences the quality and quantity of higher education (Nabi, et al, 2013).
Over the years, Ghanaian universities have increased their program offerings and expanded some of their faculties and infrastructure to satisfy changing academic demands as well as the country's expanding demand for higher education. Distance education (DE) for teachers is one of the innovations that the University of Cape Coast (UCC) has implemented in Ghana. (Akuamoah-Boateng, Sam-Tagoe and Brown (2012)

The provision of student support services is one aspect that adds to student happiness in tertiary education (Pam \& Dunworth, 2012). To help students cope with their academics, tertiary institutions provide support services such as face-to-face tutorials and administrative services.

Following the launch of distant education programs in Ghana, however, far less attention has been dedicated to providing support services for students. This has resulted in poor academic performance, psychological trauma dropouts, and poor academic performance among students.. (Fluke, O’Connor, Strawhun, \& 
Peterson, 2014; Mehran \& Mahdi, 2010). If a long-term remedy is not established through a thorough research study, this problem could become serious, leading to greater psychological stress, dropout, and other problems. Several research (SamTagoe and Akomaoh-Boateng, 2018; Sakyi, 2013; Shikulo and Lekhetho, 2020;) have mostly focused on assessment and student support services in general for distance education students at the University of Cape Coast in Ghana and abroad. However, their research focused less on the impact of face-toface tutorials and administrative services on academic performance, necessitating this research.

\section{Purpose of the Study}

The goal of the study was to see how face-to-face tutorials and administrative services affect students' academic performance in most of the institution's (University of Cape Coast) designated study centres in order to improve distance education delivery in UCC.

The study's precise aims were to:

1)Examine the link between face-to-face tutorials and academic performance.

2) Investigate the link between administrative support services and academic performance

\section{Hypothesis}

The following hypotheses were formulated to guide the study

1. H0: There is no statistically significant relationship between face-to-face tutorials and academic performance (CGPA)

2. H1: There is a statistically significant relationship between face-to-face tutorials and academic performance (CGPA)

3. H0: There is no statistically significant relationship between administrative support and academic performance (CGPA).

4. H1: There is a statistically significant relationship between administrative support and academic performance (CGPA).

\section{Diagnosis The concept of distance education}

Distance education has been defined in a variety of ways by academics and researchers in the field of education. Distance education (DE) "is a learning process in which the teacher and the learner are separated in terms of space and time; communication between the two is mediated by print media or ICT, and learning is under the control of the learner rather than the teacher," according to Mnyanyi \& Mbwette (2009).According to Commonwealth Learning (2004), distance education is a teaching and learning platform in which course materials are sent to learners who are separated by location and time.The basic premise of distant education is that learners and instructors are separated by time and distance. In actuality, the nature of distant education varies greatly from one country to the next. Distance education is defined in most advanced countries as online interactions and learning with no physical connections between teachers and students (Jamilatu, Ankoma-Sey, Asamoah, \& Quansah, 2020).
A wide range of theoretical philosophies have been developed to provide a deeper knowledge of the learner at a distance. Transactional distance is one such concept. Moore's (1990) concept of "transactional distance" encompasses the distance that exists in all educational relationships. This distance is determined by the amount of dialogue that occurs between the learner and the instructor, and the amount of structure that exists in the design of the course. Greater transactional distance occurs when an educational programme has more structure and less studentteacher dialogue, as might be found in some traditional distance education programmes. Saba and Shearer (1994) carry the concept of transactional distance a step further by proposing a system dynamics model to examine the relationship between dialogue and structure in the transactional distance. According to Saba and Shearer's findings, transactional distance reduces as learner control and dialogue rise. The amount of transaction between the learner and the instructor, not the location, affects the effect of training. This approach has ramifications for the delivery of distance learning. As a result, Student Support Services may be able to facilitate a wider range of transactions while also improving interaction to reduce transactional distance.

\section{Student support service}

Students are the reason that educational institutions exist. As a result, it is necessary for these institutions to meet the basic requirements of students, whether they arise in the classroom or outside of it. Student support services are the efforts of educational institutions to meet the requirements of students. Support services for students have properly become a "key job" of educational institutions (Haddad \& Altbach, 2009).

These programs' major purpose is to ensure that children's academic, physical, moral, social, and spiritual development. These services allow students to concentrate on their studies. As a result, Morgan (2012) correctly defines student support services as all "services" that help students study. Similarly, Shikulo \& Lekhetho (2020) stated that excellent student support services at higher education institutions (HEIs) are critical, especially in the ever-changing distance education landscape. This is crucial because HEIs are becoming more competitive, and they must deliver high-quality education to remain competitive. This can be accomplished by providing good support services to students (their consumers), without which they will seek out alternative universities. Organizations and institutions must give quality services to clients, take a customerled strategy, and not expect their "product" or service to sell itself in order to stay in business. Herman, Jancey, and Burns, Tait, Herman, Jancey, and Burns (as cited in Shikulo \& Lekhetho, 2020). As a result, HEIs, particularly ODLs, should provide effective support services that match students' specific needs, enhance their learning experience and academic achievement, and empower them to be self-directed lifelong learners.

\section{Face-to-face Tutorial Session}

Face to face tutorial sessions are in-person classes (called faceto-face sessions) held on weekends (i.e. Saturdays and Sundays) using various classroom facilities in senior high schools, colleges, and universities as satellite campuses (i.e. study centres) with the assistance of course tutors to facilitate learning, according to Jamilatu, et.al (2020).

The most prevalent method of providing tutorial contact services to distance students, particularly in poor countries, is face-to-face 
engagement. These tutorial meetings are mediated by an appointed tutor who provides further explanations on pertinent course content, primarily in response to queries posed by students (Sakyi, 2013). Sakyi, agree that face-to-face tutorial sessions are critical to academic achievement in DE, and that without them, students will fall short. One of the most significant aspects of tutorials is that they bring students and tutors together in person to engage and improve the teaching and learning experience.

'The tutor's responsibility is to mark assignments with thorough formative input and to provide support to students as appropriate,' according to Jelfs, Richardson, and Price (2009). (p. 4).

Sakyi also recognizes that tutors' primary role is to make learning materials more understandable, but they are also expected to motivate and encourage students in the following ways: Assignments as a means of bolstering tutoring; Inventing new strategies to encourage student interaction; assisting students in their academic progress; Being available to help students at all times.

\section{Administrative Support Services}

Administrative assistance in DE, according to Welch and Reed (as cited in Sakyi, 2013), seeks to provide adequate facilities and learning resources to distance students. All information on entrance, registration, examinations, and timetables is included in administrative support. It also includes making academic progress reports available to pupils upon request. In fact, every administrative help supplied to students and professors contributes to the institution's general well-being (Sakyi, 2013). The University of Birmingham Code of Practice for Distance Learning (2012-13: 9) states that prospective students should have direct access to information about: the admission requirements of the program, especially where these include access to resources, hardware, and/or software, and whether ongoing access to these is a requirement for continued registration on the program; the expectations, including time commitment, that would be placed on them as distance learners; and the expectations, including time commitment, that would be placed on them as distance learners. Any demand for attendance at any location at any time during the program; any additional program fees, such as travel and sustenance; or any necessary provision for personal tutors to visit the student's location. (Source: University of Birmingham Distance Learning Code of Practice, 2013-14:9)

In addition, Zhang, Dwumah, Adjei, Mingyue, and Oduro (2019) conducted research on the impact of school administration functions on students' academic performance: A conundrum from Ghana's public senior high schools. The study's findings revealed that school administration functions had an impact on students' academic achievement

\section{Methodology:}

Explanatory Sequential Mixed Method Design was used in this study. The explanatory sequential mixed methods approach is defined by Creswell (2014) as a mixed methods design that appeals to persons with a strong quantitative background or from fields that are new to qualitative techniques. It is a two-part study in which the researcher collects quantitative data in the first phase, analyzes the results, and then plans (or builds upon) the qualitative phase in the second. The researcher contacted study participants, conducted interviews (data collection), analyzed data results (transcribed, coded, themes), and interpreted qualitative results in the second phase. Explanatory sequential mixed methods aid in the development of deep insights into a variety of phenomena that cannot be fully comprehended using only a quantitative or qualitative method, (Viswanath) (2013). The crucial premise of mixed method design, according to Creswell and Plano Clark (2014), is that using qualitative and quantitative methods in tandem will provide a greater grasp of the research challenges than using either approach alone in a study. This is said to be one of, if not the most important, foundations of pragmatic philosophical thinking in today's study (Ihuah \& Eaton, 2013).

\section{Population:}

The undergraduate students were chosen for the study because the length of their program may have exposed them to a variety of experiences and knowledge about the impact of student support services on academic achievement. As of 2020, there were 6808 distance students enrolled in the three zones' designated study centres.(Kumasi Anglican SHS, Kumasi Technical Institute, Wesley College, Tema Lutheran School, (Student Records Management Unit, CoDE, 2020).

The sample distribution depending on the study centres is shown in Table 1.

Table 1: Distribution of Samples Based on Study Centres

\begin{tabular}{|l|c|}
\hline \multicolumn{1}{|c|}{ Study Centres } & \multicolumn{1}{c|}{$\begin{array}{c}\text { Population } \\
\text { students }\end{array}$} \\
\hline $\begin{array}{l}\text { Kumasi } \\
\text { Anglican SHS }\end{array}$ & 471 \\
\hline $\begin{array}{l}\text { Kumasi } \\
\text { Technical Inst. }\end{array}$ & 1174 \\
\hline Wesley College & 893 \\
\hline $\begin{array}{l}\text { Lutheran } \\
\text { school-Tema }\end{array}$ & 804 \\
\hline $\begin{array}{l}\text { Lutheran } \\
\text { school-Madina }\end{array}$ & 754 \\
\hline $\begin{array}{l}\text { Lutheran } \\
\text { school-Kanda }\end{array}$ & 685 \\
\hline $\begin{array}{l}\text { Tamale Training } \\
\text { College }\end{array}$ & 1105 \\
\hline $\begin{array}{l}\text { Tamale } \\
\text { Polytechnic }\end{array}$ & 682 \\
\hline Gambaga & 6808 \\
\hline Total
\end{tabular}

Source: Student Records Management Unit, CoDE (2020) 
In order to choose respondents from the UCC DE program, the researcher used a multi-staged approach that included stratified and simple random sampling procedures.

This was done to make sure the findings were more reflective of the intended demographic.

\section{Sampling}

Ten regions were divided into three zones or strata (southern, middle, Northern).For the study, the regions with the biggest student population and study programs were chosen. Within the three (3) regions, the researcher chose three (3) study centers with the most students to constitute the study's major sampling size. These locations were chosen to help researchers gain a better understanding of the impact of support services on academic performance across the country. The researcher chose a sample size of 6808 pupils because he thought these figures were both practical and representative of the entire population. In addition, simple random sampling was employed. In addition, respondents for the study were chosen using simple random selection. The real sample size was calculated using Slovin's Formula $(\mathrm{n}=\mathrm{N} /(1+\mathrm{Ne} 2))$. Where $\mathrm{n}$ denotes the number of samples, $\mathrm{N}$ denotes the total population, and e denotes the error tolerance (level). The needed sample size for 6808 was 378 according on Slovin'sFormula. Refer to table 2

Table 2: Stratified Sample for Students in Selected Study Centres

\begin{tabular}{|l|c|c|c|}
\hline $\begin{array}{l}\text { Study } \\
\text { Centre }\end{array}$ & $\begin{array}{c}\text { Number } \\
\text { of } \\
\text { student }\end{array}$ & $\begin{array}{c}\text { Proportionally } \\
\text { allocated } \\
\text { sample size of } \\
\text { students }\end{array}$ & $\begin{array}{c}\text { Percentage } \\
\text { of students } \\
\text { (\%) }\end{array}$ \\
\hline $\begin{array}{l}\text { Kumasi } \\
\text { Anglican } \\
\text { SHS }\end{array}$ & 471 & 26 & $7 \%$ \\
\hline $\begin{array}{l}\text { Kumasi } \\
\text { Technical } \\
\text { Inst }\end{array}$ & 1174 & 65 & $17 \%$ \\
\hline $\begin{array}{l}\text { Wesley } \\
\text { College }\end{array}$ & 873 & 50 & $13 \%$ \\
\hline $\begin{array}{l}\text { Lutheran } \\
\text { school- } \\
\text { Tema }\end{array}$ & 804 & 45 & $12 \%$ \\
\hline $\begin{array}{l}\text { Lutheran } \\
\text { school- } \\
\text { Madina }\end{array}$ & 754 & 42 & $11 \%$ \\
\hline $\begin{array}{l}\text { Lutheran } \\
\text { School- } \\
\text { Kanda }\end{array}$ & 685 & 38 & $10 \%$ \\
\hline $\begin{array}{l}\text { Tamale } \\
\text { Training } \\
\text { College }\end{array}$ & 1105 & 61 & $16 \%$ \\
\hline $\begin{array}{l}\text { Tamale } \\
\text { Polytechnic }\end{array}$ & 482 & 27 & $1 \%$ \\
\hline $\begin{array}{l}\text { Gambaga } \\
\text { study centre }\end{array}$ & 440 & $\mathbf{3}$ & \\
\hline $\begin{array}{l}\text { Total } \\
\text { Source }\end{array}$ & $\mathbf{6 8 0 8}$ & & \\
\hline
\end{tabular}

Source: Field survey (2020)
The purposive sample method was utilized to select 9 distance education students to participate in the interview for the qualitative segment. Four males and five female students from the designated study centers make up this sample.

The purposeful sample was employed, which means that individuals were chosen with the objective of learning and understanding the central phenomenon (Finch, 2018). The objective was to handpick volunteers who would provide the greatest answers to the research questions and who were "information-rich" (Finch, 2018). Because of the mixed-method study's explanatory sequential design, participants were chosen for the qualitative phase based on their engagement in the Student Support Service. Questionnaire and outliers from a Pearson Moment Correlation to improve the researchers understanding of the quantitative results in phase one.

Participants had to submit their phone numbers on the form and consent to being contacted for an interview in order to be included for the initial pool. To be reached, such responders were requested to supply their phone numbers and email addresses. When possible, the researcher chose participants who represented both genders, a range of ages and years of experience in distance learning at the University of Cape Coast, and who expressed at least a minor level of dissatisfaction with one or more of the University of Cape Coast's student support services. Nine pupils were contacted, three from each of the three zones (Southern, Middle, and Northern). If a person rejected to participate in the study's second phase, the researcher looked for a substitute candidate who was most similar to the original participant within the appropriate group. Nine students were contacted, three from each of the study centres' zones (Southern, Middle, and Northern). This number was chosen since it accurately depicts the zones and their pupils.

\section{Data collection instrument}

The instruments that were used to collect data for the study were:

1. Survey questionnaire on the effect of students support services and academic performance

2. Semi- structure Interview guide on the effect of students support services and academic performance

\section{Pilot}

A pilot was conducted on 40 undergraduate distance education students. The pilot was conducted at Akwamuman Senior High School study center in the Eastern region of Ghana on the 23rd January 2021.

\section{Research Ethics Statement}

All legal laws and regulations were followed to the letter.The University of Cape Coast's Institutional Review Board, for example, granted permission to perform the study.

The respondents' personal information has been disaggregated to safeguard their anonymity.

\section{Data Analysis}

The quantitative and qualitative data were analysed separately given the different nature of the data; however, after analyzing the data were integrated and triangulated to answer the research questions in this study. For the quantitative part means, standard deviation and Person Moment Correction were used and for the qualitative part, the data was coded put under transcribed and themes. 


\section{Results and Discussion}

Analysis of the demographic characteristics of respondents Gender, marital status, and study centre are the demographic features of respondents that are presented. The analysis of demographic factors of respondents is summarized in Tables 3 to 5 .

Table 3 shows the gender of the responders. Table 3 shows that $149(39.8 \%)$ of the survey respondents were males, while 225 $(60.2 \%)$ were females.

Table 3: Gender of Respondents

\begin{tabular}{llll}
\hline & & Frequency & Percentage \\
\hline \multirow{3}{*}{ Valid } & Male & 149 & 39.8 \\
& & & \\
& Female & 225 & 60.2 \\
& & & \\
\hline & Total & 374 & 100.0 \\
\hline
\end{tabular}

Source: Field data (2021)

The results show that the study surveyed more female distant education students than male distance education students.

Table 4 shows the marital status of the respondents. 278 $(74.3 \%)$ of those polled were single, $94(35.1 \%)$ were married, and 0.3 present were divorced or widowed.

Table 4: Marital Status of Respondents

\begin{tabular}{cccc}
\hline & Frequency & Percent \\
\hline \multirow{3}{*}{ Valid } & Single & 278 & 74.3 \\
& Married & 94 & 25.1 \\
& Divorced & 1 & 0.3 \\
& Windowed & 1 & 0.3 \\
\hline Total & $\mathbf{3 7 4}$ & $\mathbf{1 0 0 . 0}$ \\
\hline Source: Filed survey (2021) & &
\end{tabular}

Source: Filed survey (2021).

The bulk of the respondents were single, according to the findings.

This suggests that the vast majority of the distance education students questioned were not married. Because the majority of them were still young, this finding was obvious.

Table 5 shows the study centre of the respondents

\begin{tabular}{|c|l|c|c|}
\hline \multicolumn{2}{|c|}{} & Frequency & Per cent \\
\hline \multirow{7}{*}{ Valid } & $\begin{array}{l}\text { Gambaga } \\
\text { Study Centre }\end{array}$ & 24 & 6.4 \\
\cline { 2 - 4 } & $\begin{array}{l}\text { Kumasi } \\
\text { Anglican SHS }\end{array}$ & 26 & 7.0 \\
\cline { 2 - 4 } & $\begin{array}{l}\text { Kumasi } \\
\text { Technical } \\
\text { Institute }\end{array}$ & 65 & 17.4 \\
\cline { 2 - 4 } & $\begin{array}{l}\text { Lutheran } \\
\text { School Kanda }\end{array}$ & 38 & 10.2 \\
\cline { 2 - 4 } & $\begin{array}{l}\text { Lutheran } \\
\text { School } \\
\text { Madina }\end{array}$ & 52 & 13.9 \\
\cline { 2 - 4 } & $\begin{array}{l}\text { Lutheran } \\
\text { School Tema }\end{array}$ & 45 & 12.0 \\
\cline { 2 - 4 } & \begin{tabular}{l} 
Tamale Poly \\
\cline { 2 - 4 }
\end{tabular} & 26 & 7.0 \\
\cline { 2 - 4 } & $\begin{array}{l}\text { Tamale } \\
\text { Training } \\
\text { College }\end{array}$ & 48 & 12.8 \\
\cline { 2 - 4 } & $\begin{array}{l}\text { Wesley } \\
\text { College }\end{array}$ & 50 & 13.4 \\
\hline & Total & 374 & 100.0 \\
\hline
\end{tabular}

Source: Field survey (2021).

Table 5 shows that out of the surveyed respondents, 24 (6.4 present) were from the Gambaga study centre, representing the lowest respondents, and 65 (17.4\%) were from Kumasi Technical Institute, representing the highest respondents. This meant that the majority of the respondents came from Kumasi Technical Institute, while Gambaga had the least number of respondents.

According to the findings, 141 (37.7\%) of the respondents were from the Ashanti Region (Middle Zone), 98 (26.2\%) from the northern zone, and 135 (36.1\%) from the Greater Accra zone (Southern Zone).According to the findings, the bulk of those polled for the study were from the Middle Zone (Ashanti Region).

\section{Research Objective one}

The initial goal was to look into the relationship between face-toface tutorials and academic achievement of University of Cape Coast distant education students.

For this goal, the following hypothesis was developed:

- H0: There is no statistically significant link between faceto-face tutorials and academic performance of University of Cape Coast distant education students.

- H1: There is a statistically significant link between faceto-face tutorials and academic achievement of University of Cape Coast distant education students.

To achieve the purpose and test the null hypothesis, Pearson Product-Moment Corr. was utilized (H0).Academic performance was measured by students' cumulative grade point averages (CGPAs), while face-to-face service was determined by composite scores generated with SPSS.

The $\mathrm{H} 0$ hypothesis was tested at a $\%$ significance level, and the results are summarized in Table 6. 
Table 6: Relationship between Face-to-Face Tutorial and Academic Performance

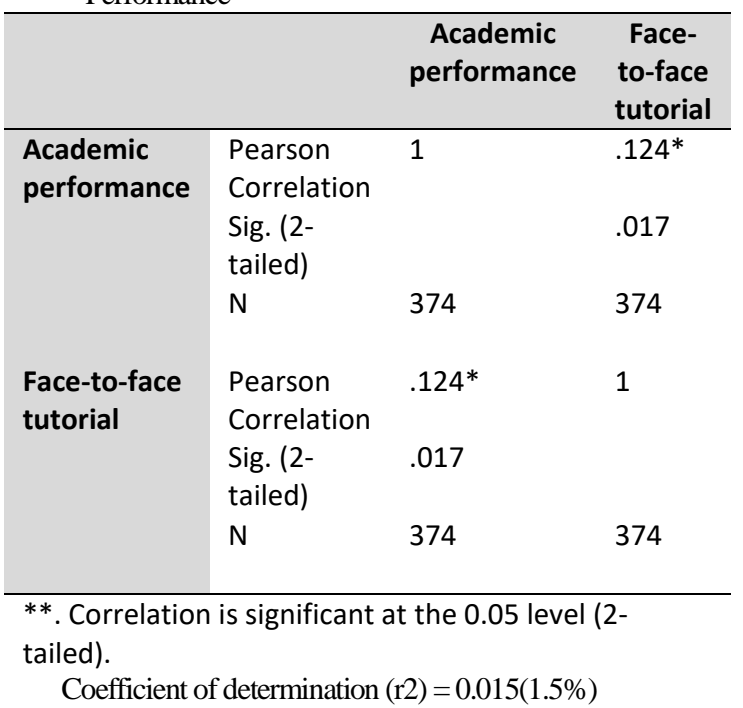

Table 6 shows a significant positive but weak link between faceto-face tutorial service and academic achievement of University of Cape Coast distant education students $(r=0.124$, $p=0.170 .05)$. $\mathrm{H} 0$ is rejected out in favour of H1. The findings show that the university's efforts to increase the provision of face-to-face services to distance education students would result in improved academic achievement. However, there isn't much of a difference in performance as a result of providing face-to-face instructional services. The availability of face-to-face services accounts for only 1.5 present of the variances in students' academic achievement, according to the coefficient of determination. To back up this claim, the results of the interview revealed that distance education students at the University of Cape Coast had a positive perception of face-to-face tutorials as student support services, as well as a significant preference for them. The following are excerpts to confirm this finding:-

\section{Participant one said;}

"The face to face help because some of us we have home problems, relationship issues, financial problems so when you get out of your home you don't take this problem along though when you stay at home you can read your modules but need the knowledge of the tutor to guide you, sometimes some of the things are technical so with the help of the tutors you get the understanding" (Respondent 6)

\section{Other participants said:}

"As I said earlier on face to face help us a lot because when you read the books through the explanation of the tutors you will get the main concept and understanding to write the quizzes and examination and I perform well through that". (Respondent 9)

Another participant had this to say:

"Face to face help us, assuming I am in the house learning alone, and I come across a word or a sentence but the understanding is difficult for me, if I come for face to face I ask the tutors and they provide answers to them and that helps me to perform well". (Respondent 3)

Another participant also said:

"It helps us a lot because we the distance students normally don't have time for our books so when you have an encounter with the tutors they make us understand much better about the unit we are not able to capture during our free period at home" (Respondent 5)

It can be inferred from the above that distance education students are happy with the face to face tutorial and how it helped them to perform well in their examination.

\section{Research Objective two}

The two objectives sought to examine the relationship between administrative support and academic performance of distance education of students of the University of Cape Coast. The hypothesis postulated for this objective was:

- H0: There is no statistically significant relationship between administrative support and academic performance of distance education students of the University of Cape Coast.

- H1: There is a statistically significant relationship between administrative support and academic performance of distance education students of the University of Cape Coast.

Pearson Product Moment Correction was used to achieve the goal of the objective and test the null hypothesis (H0), because administrative support and academic performance were continuous, administrative support was categorical (since it was measured on a five-point scale namely; strongly agree, agree; neutral, disagree, strongly disagree), and academic performance was measured on an interval scale (Fields, 2009).Academic performance was measured by students' cumulative grade point averages (CGPAs), and administrative support was measured by composite ratings generated with SPSS.

The H0 hypothesis was tested at a 5\% significance level, and the results are summarized in Table 7.

Table 6: Relationship between Administrative Support and Academic Performance

\begin{tabular}{llll}
\hline & & $\begin{array}{l}\text { Academic } \\
\text { performance }\end{array}$ & $\begin{array}{l}\text { Administrative } \\
\text { services }\end{array}$ \\
\hline $\begin{array}{l}\text { Academic } \\
\text { performance }\end{array}$ & $\begin{array}{l}\text { Pearson } \\
\text { Correlation } \\
\text { Sig. (2- } \\
\text { tailed) } \\
\mathrm{N}\end{array}$ & 1 & $.499 * *$ \\
Administrative & $\begin{array}{l}\text { Pearson } \\
\text { services }\end{array}$ & $.499 * *$ & 374 \\
\hline $\begin{array}{l}\text { Correlation } \\
\text { Sig. (2- } \\
\text { tailed) } \\
\mathrm{N}\end{array}$ & .000 & 1 \\
\hline
\end{tabular}

**. Correlation is significant at the 0.01 level (2-tailed).

Coefficient of determination $(\mathrm{r} 2)=0.25(25.0 \%)$

Table 7 shows a modest significant positive link between administrative services and academic achievement of University of Cape Coast distance education students ( $\mathrm{r}=0.499$, p0.001). $\mathrm{H} 0$ is ruled out in favour of $\mathrm{H} 1$.The findings show that providing high levels of administrative support to distant education students will result in high academic success.

The provision of administrative support services accounts for only 25.0 present of the variances in students' academic 
achievement, according to the coefficient of determination. This shows that administrative support services play an important role in the University of Cape Coast's remote education program. This suggests that administrative support services have a critical relationship and contributor to University of Cape Coast distance education students' performance

To validate this result, the following excerpt from the interview confirmed this finding:-

\section{One of the participants said:}

"I think the problems come from $\mathrm{CoDE}$ if they can resolve all our needs like modules and provide immediate feedback on our problems, it will even ginger us to learn hard but sometimes with our quizzes we have being writing for instance, we complain a lot and nothing comes out, so we are always like they are doing the same thing all the time is it affecting our studies". (Respondents 5)

\section{Another participant said:}

"The administrative support is very bad because when we sent a report or complain we don't get feedback. This discourages us from learning because if you have a problem with your result and you report and no feedback is obtained, it demoralizes you from learning". (Respondent 4)

Another respondent had this to say:

"If problems are resolved it helps a lot especially with the modules, if we raise the concern of our modules not being adequate and the remaining are brought, it helps the students to learn. In a situation where modules are not up our number but the students are forced to write quizzes and exams, it has not been easy at all, at times they ask us to download the module from the portal, at the time we can't access it from the portal". (Respondent 7)

The result showed that distance education students have a bad perception of the administrative support services provided and believed that if the administrative support system is improved it will help them to perform well academically.

\section{Discussion of Results}

The initial goal was to look into the relationship between face-toface tutorials and academic achievement of University of Cape Coast distant education students.

The study found a substantial favorable but modest link between face-to-face tutorial service and academic achievement of University of Cape Coast distant education students.

The findings demonstrate the value of face-to-face tutorials for distance students and how they improve their academic performance. As can be seen from the discussion above, the students who were polled firmly agreed that face-to-face tutorials help them improve their academic performance. As a result, it's critical that the College of Distance Education encourages their tutors to keep working harder to attain the required results.

These findings back up Olivier's (2016) research on the impact of contact sessions and discussion forums on open distance learning students' academic achievement in South Africa.

Students who attended a written assignment preparation contact session fared much better in the written assignment than students who did not attend this contact session, according to the findings.
Lesiba and Mothudi (2014) conducted a similar study titled "effect of face to face tutorials on learning outcomes "an example from UNISA's Ekurhuleni Regional Service Centre."

The study found that students who attended tutorials performed better on their exams, implying that tutorials have a positive impact on academic achievement.

However, it contrasts recent research by Moula and Maithya (2011), which found no significant correlation between face-toface tutoring and academic success.

The following finding suggests that the University of Cape Coast's College of Distance students are satisfied with the faceto-face tutorial's performance. Students reported that course tutors give them better and more detailed explanations of some complex ideas, and that these explanations assist them grasp the courses they are taking, resulting in improved performance. Due to circumstances beyond their control, some students acknowledged to missing the weekend lectures. Others have stated that they are unable to fully utilize the weekend lessons provided for them due to a delay in the delivery of course modules.

Students were usually delighted and satisfied with the face-toface session, according to the findings. The second goal was to look into the link between administrative support and academic achievement of University of Cape Coast distant education students. The study's findings demonstrated that administrative support services had a significant impact on distance education students' performance at the University of Cape Coast.

According to Sakyi, (2013), administrative assistance in distant education focuses on providing suitable facilities and learning resources to distance students. All information on entrance, registration, examinations, and timetables is included in administrative support. It also includes making academic progress reports available to pupils upon request. In fact, every administrative help supplied to students and professors contributes to the institution's general well-being (Sakyi, 2013).In this regard, Mwangi (2015) asserted that efficient administrative support aids in the improvement of student performance. The findings support the findings of Keieti, Msithya, and Mulwa (2017), who concluded that administrative practices had a strong positive and significant impact on academic achievement. This finding also agrees with Charles (2019) who was of the view that administrative support and utilization of materials significantly influence students' academic performance.

The fact that distance students were dissatisfied with the administrative support services supplied by the College of Distance Education can be deduced. Students complained about delays in receiving course modules as well as bureaucratic procedures in resolving academic concerns such as results, modules, and exams. Students have to pay more money to have their difficulties fixed. They must come to Cape Coast to pursue their issues and get them addressed by officials.

Again, it is clear that a significant number of students polled disagree that administrative support services assist them in performing well in their academics.

During the interview, however, respondents indicated that if the institution implements effective and efficient administrative support services, it will assist students in performing well in their studies. 


\section{Summary of Key Findings}

The initial goal was to look into the relationship between face-to-face tutorials and the academic achievement of University of Cape Coast distant education students. The study found a substantial favourable but modest link between face-to-face tutorial service and academic achievement of University of Cape Coast distant education students.

The second goal was to look into the link between administrative support and academic achievement among University of Cape Coast distant education students.

The study discovered a weak but substantial beneficial link between administrative services and distance education students' academic performance.

\section{Recommendations}

The following recommendations were made based on the study's findings:

1) Because face-to-face meetings have been shown to boost academic achievement, the study suggests that course tutors be trained in distance education course delivery methodologies and facilitation abilities in order to increase student success. This could provide them with excellent student assistance skills as well as engaging teaching methods that encourage students to study independently and critically. Facilitators should also be educated on how to effectively employ relevant ICTs to bridge the transactional gap that exists in distant learning.

2) The study also suggests that administrative support services be increased in order to give students with more efficient services. CoDE should also maximize the use of multimedia and social media to encourage students, particularly those in rural regions, to engage in debate. In the same vein, it should look for ways to give individualized, one-on-one help for students that is tailored to their specific requirements (Tait, 2004).

3) Study suggest that the university takes the necessary steps to train administrators in distance learning techniques in order to improve students services

4) The study also suggested that the institution of distance education construct a competency assessment scale for administrators so that students can evaluate them in order for them to offer the best work possible.

\section{Acknowledgment}

I wish to acknowledge the patience, commitment and constructive suggestions of my supervisors, Dr Samuel Yaw Ampofo and Ernst Thoutenhoofd who dedicated their precious time out of their tight schedules, to offer intellectual support, coaching, and mentorship.

I have no conflicts of interest to disclose and no funding has been received

\section{References}

[1] Asamoah (2018) Perceived causes of low academic performance of senior high students in core mathematics in the Kumasi metropolis of the Ashanti Region of Ghana.( Master's Thesis Administration and Policy Studies, 12(1), 43-5

[2] Boateng, Sam-Tagoe and Brown (2012) Distance Teacher Trainee Perception of Teaching Practice Mentors at the University of Cape Coast, Ghana. Advances in Social Sciences Research Journal. 10.14738/assrj.58.4931

[3] Charles, O. (2019). Effect of administrative materials on students' academic performance in Biology in Abi Local Government area of cross river state. (4th ed.). Thousand Oaks, CA: Sage.

[4] Commonwealth of Learning (CoL) (2004). Defining open distance learning.

[5] Cooper, M. (2010). Student support services at community college: a strategy for increasing student persistence and attainment.

[6] Cresswell, J. W., \& Plano-Clark, V. L. (2011). Designing and conducting mixed methods research. (2nd ed.). Thousand Oaks, CA: Sage.

[7] Creswell, J. W. (2014). Qualitative inquiry and research design: choosing among five approaches. (2rd ed). New Delhi: Sage Publications.

[8] Creswell, J. W. (2014). Research design: Qualitative, quantitative and mixed methods approach

[9] Cummings, Andrea Marie,(2014) "The Impact of Student Support Services on Academic Success at a Select Historically Black College and University" (2014). UNF Graduate Theses and Dissertations. 532.https://digitalcommons.unf.edu/etd/532

[10] Education, Arts and Sciences, 2017

[11] Fields,A.(2009).Discovering statistics using SPSS:Introducing statiscal method (3rded.).Thousand Oak,CA:Sage Publication

[12] Fluke, S., O’Connor, A., Strawhun, J., \& Peterson, R. L. (2014). Academic supports and tutoring, strategy brief.

[13] Gay, L. R., Mills, G. E., \& Airasian, P. (2009). Educational research: Competencies for analysis and applications. 9th ed. London: Pearson Education.

[14] Jamilatu, S., Ankoma-Sey, V. R., Asamoah. D., \& Quansah. F. (2020). Conducting research work as a requirement for university undergraduate studies: Challenges of distance

[15] Jelfs, A., Richardson, J. T. E., \& Price, L. (2009). Student and tutor perceptions of effective tutoring in distance education. Distance Education, 30(3), 419441education students in Ghana. Open Education Studies, 2, 149-158.

[16] Josephine Sam-Tagoe\& Clara AkuamoahBoateng,(2018) Supporting Distance Learners' for Success at University of Cape Coast, Ghana Learners' esis,UCC)

[17] Keieti. J. M., Msithya. R., \& Mulwa, D. M. (2017). Influence of administrative practices on students' academic performance in public secondary schools in 
Matungulu sub country, Kenya. International Journal of Education and Research, 5, 15-17

[18] Mark Nichols (2010) Student perceptions of support services and the influence of targeted interventions on retention in distance education, Distance Education, $\quad 31: 1, \quad 93-113, \quad$ DOI: $10.1080 / 01587911003725048$

[19] Mehran, F., \& Mahdi. M. (2010). The study of relation between students support services and distance students' academic achievement. Procedia Social and Behavioral Sciences, 2(2010), 44514456.

[20] Moore's (1990) Michael Moore (1990) Recent contributions to the theory of distance education, Open Learning: The Journal of Open, Distance and e-Learning, $\quad 5: 3, \quad 10-15, \quad$ DOI: 10.1080/0268051900050303

[21] Mwangi, P. M. (2015). Administrative factors influencing students' performance in Kenya Certificate of Secondary education in public day secondary schools in Thika West District, Kenya. (A Research Project). University of Nairobi.

[22] Pallant, J. (2010). SPSS survival manual (4th ed.). New York, NY: McGraw

[23] Pam, R., \& Dunworth, K. (2012). Staff and student perceptions of support services for international students in higher education: A case study. Journal of Higher Education Policy and Management, 34(5), 517-528.

[24] Petra, B., \& Nokuthula T. N. (2018). Students' perceptions of student support services at a nursing campus. Africa Journal of Nursing and Midwifery, 5, 31-48.

[25] Saba, F. \& Shearer, R.L. (1994). Verifying Key Theoretical Concepts in a Dynamic Model of Distance Education. American Journal of Distance Education, 8(1), 36-59. Retrieved September 25, 2021.

[26] Sakyi, U. (2013). Appraisal of student support services in distance education at University of Cape Coast. (Master's thesis). University of Ghana.

[27] Sánchez-Elvira, K., Paniagua, A., \& Simpson, O. (2018). Developing student support for open and distance learning: The EMPOWER project. Journal of Interactive Media in Education, 1(9), 1-10.

[28] Santhi, B., Noor, A. A., \& Nasirudeen, A. M. (2014). Factors Contributing to Academic Performance of Students in a Tertiary Institution in Singapore. American Journal of Educational Research, 2, 752758.

[29] Shikulo, L., \& Lekhetho, M. (Reviewing editor) (2020). Exploring student support services of a distance learning centre at a Namibian university. Cogent Social Sciences, 6(1), 17-19.

[30] The Glossary of Quality Assurance in Japanese Higher Education (2016)

[31] The University of Birmingham Code of Practice for Distance Learning (2012-13: 9)
[32] Ukwueze, A. (2018). Integrating Information and communication technology for effective learning outcome in open and distance education in Nigeria. Huria Journal, 25(2), 58-67.

[33] UNESCO (2004). Final report of the meeting of higher education partners (World Conference on Higher Education + 5) UNESCO, Paris, 23-25 June 2003

[34] Wanami, Simon ; Kintu \& Denis (2019) Students 'perceptions about a distance learning programme: A case of the open, distance and E-learning programme at Kyambogo University, Uganda. International Journal of Advance Research, Ideas and Innovation in T Viswanath (2013). Bridging the QualitativeQuantitative Divide: Guidelines for Conducting Mixed Methods. Research is Information Systems," MIS Quarterly, (37: 1) pp.21-54

[35] Workman, J. J., \& Stenard, R. A. (1996). Student support services for distance learners. DEOSNEWS, $6(3), 1-11$.

[36] Zhang, H., Dwumah, B. M., Adjei, M. B., Mingyue, F., \& Oduro, D. (2019) exploring the effect of school management function on students' academic performance: A dilemma from public senior high schools in Ghana. Journal of Arts \& Humanity.

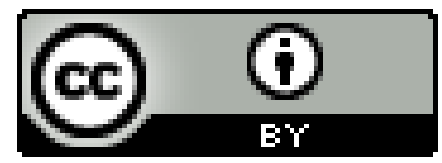

